\title{
Glutamine levels in patients with traumatic brain injury and subarachnoid haemorrhage
}

\author{
J van Rosmalen ${ }^{1 *}$, BS Jakobs ${ }^{2}$, P Vos ${ }^{1}$, HMF Kuijsten ${ }^{1}$, JAH van Oers ${ }^{1}$, D Ramnarain ${ }^{1}$ \\ From ESICM LIVES 2015 \\ Berlin, Germany. 3-7 October 2015
}

\section{Introduction}

In critical illness, the rapid depletion of glutamine has been associated with increased mortality [1]. This has led to the concept that early glutamine suppletion would benefit these patients.

A recent trial [2] however showed that early suppletion of glutamine was associated with an increased mortality. In a majority of patients glutamine levels were within normal range at admission. Patients with severe traumatic brain injury (TBI) and subarachnoid haemorrhage (SAH) however, were excluded in this trial. In literature no data on glutamine levels are available in critically ill neurologic patients.

\section{Objectives}

We conducted an observational pilot study measuring glutamine levels in the first week after TBI and acute SAH.

\section{Methods}

In a 30-bed intensive care unit of a teaching hospital patients admitted with TBI $(n=5)$ and SAH $(n=5)$ were selected. Plasma glutamine levels were measured at admission and on six consecutive days. Glutamine deficiency was defined as a plasma glutamine level of less than $420 \mu \mathrm{mol} / \mathrm{L}$. Optimal nutrition per patient was calculated by a dietician. Jevity ${ }^{\circledR}$ standard, Plus and HiCal (Abbott Nutrition) were used containing 0.36-0.40 gram glutamine $/ 100 \mathrm{kcal}$. Actual intake was noted in a Patient Data Management System (Metavision ${ }^{\circledR}$, iMDsoft). Data were collected in Excel (Microsoft $\left.{ }^{\circledR}\right)$ and analysed with $\operatorname{SPSS}^{\circledR}(\mathrm{IBM})$.

\section{Results}

See Table 1.

${ }^{1}$ St Elisabeth Hospital, ICU, Tilburg, Netherlands

Full list of author information is available at the end of the article
Mean glutamine level in TBI and SAH patients was $334.8 \pm 83.7 \mu \mathrm{mol} / \mathrm{L}$ and $446.8 \pm 97.4 \mu \mathrm{mol} / \mathrm{L}$ at admission. Glutamine deficiency was common: 7 out of 10 patients were deficient according to the definition (Table 1.) Optimal intake per individual was calculated to be $2022 \pm 498 \mathrm{kcal} / 120 \pm 36$ grams of protein. Due to several causes i.e. gastric retention and passage disorders, actual intake was $1480 \pm 580 \mathrm{kcal}$ and $77 \pm 35$ grams of protein, primarily via nasogastric tube feeding. This was $72 \%$ and $71 \%$ of calculated optimal calorie and protein intake. After seven days of treatment and nutritional support glutamine levels increased significantly in all patients with TBI $(451 \pm 146.5 \mu \mathrm{mol} / \mathrm{L})$ and SAH $(476 \pm 84.2 \mu \mathrm{mol} / \mathrm{L})$. In one $\mathrm{SAH}$ patient glutamine level declined but remained in normal range (Figure 1.).

\section{Conclusions}

We found low glutamine levels in 70\% of TBI and SAH patients at admission but no evidence of glutamine depletion during treatment. Intake of only $72 \%$ of

Table 1

\begin{tabular}{|c|c|c|}
\hline & $\begin{array}{l}\text { Glutamine }<420 \\
\mu \mathrm{mol} / \mathrm{L}\end{array}$ & $\begin{array}{l}\text { Glutamine }>420 \\
\mu \mathrm{mol} / \mathrm{L}\end{array}$ \\
\hline $\mathrm{N}=10$ & $\mathrm{n}=7$ & $\mathrm{n}=3$ \\
\hline Age (median, years) & 60 & 54 \\
\hline Gender (male/female, \%) & $29 / 71$ & $67 / 33$ \\
\hline $\begin{array}{l}\text { Type of patient (SAH/TBI, } \\
\%)\end{array}$ & $43 / 57$ & $67 / 33$ \\
\hline APACHE ॥ & 18.4 & 19.0 \\
\hline $\begin{array}{l}\text { Mechanical ventilation } \\
\text { (days) }\end{array}$ & 8.4 & 9.3 \\
\hline Length Of Stay (days) & 15.9 & 17.0 \\
\hline $\begin{array}{l}\text { Hospital-Length Of Stay } \\
\text { (days) }\end{array}$ & 22.1 & 40.7 \\
\hline 3-Month mortality (\%) & 57 & 0 \\
\hline
\end{tabular}




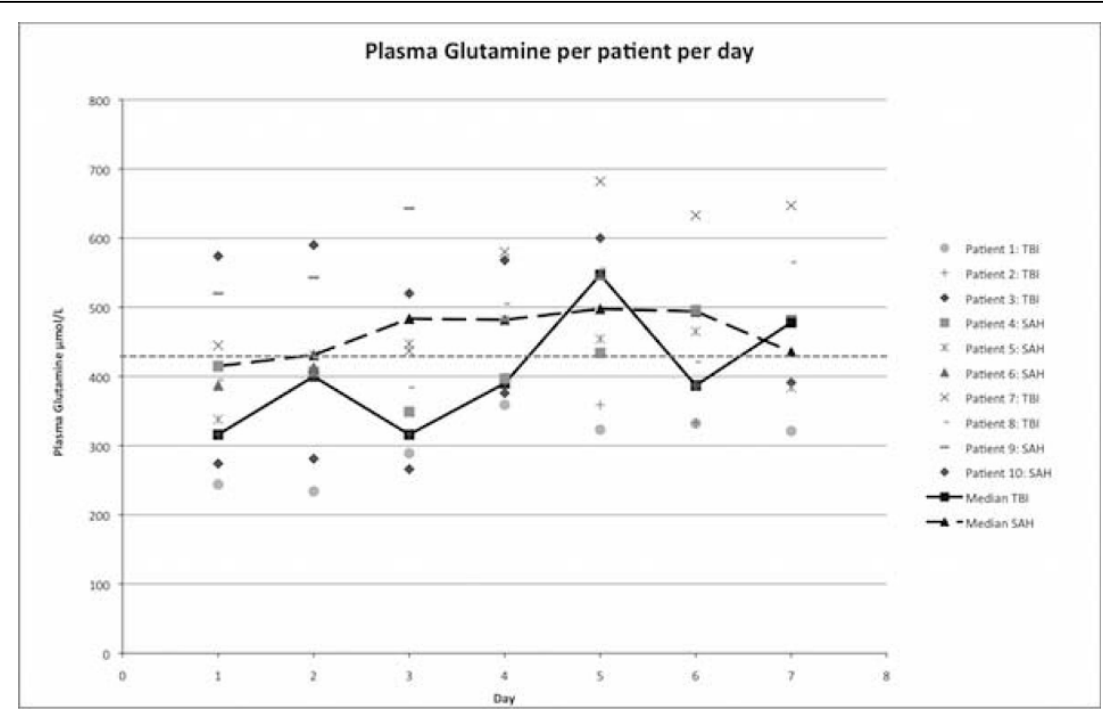

Figure 1

calculated optimal calorie intake and $71 \%$ of protein intake was sufficient to reach near-normal levels of glutamine in patients with TBI and SAH.

\section{Authors' details}

'St Elisabeth Hospital, ICU, Tilburg, Netherlands. ${ }^{2}$ St Elisabeth Hospital, KCHL, Tilburg, Netherlands.

Published: 1 October 2015

\section{References}

1. Oudemans-van Straaten HM, Bosman RJ, Treskes M, van der Spoel HJ, Zandstra DF: Plasma glutamine depletion and patient outcome in acute ICU admissions. Intensive Care Med 2001, 27(1):84-90, Jan.

2. Heyland $\mathrm{D}$, et al: $\mathrm{A}$ randomized trial of glutamine and antioxidants in critically ill patients. N Engl J Med 2013, 368(16):1489-97, Apr 18.

doi:10.1186/2197-425X-3-S1-A779

Cite this article as: van Rosmalen et al:: Glutamine levels in patients with traumatic brain injury and subarachnoid haemorrhage. Intensive Care Medicine Experimental 2015 3(Suppl 1):A779.

\section{Submit your manuscript to a SpringerOpen ${ }^{\circ}$ journal and benefit from:}

- Convenient online submission

- Rigorous peer review

- Immediate publication on acceptance

- Open access: articles freely available online

- High visibility within the field

- Retaining the copyright to your article

Submit your next manuscript at $>$ springeropen.com 